\title{
Pathological Gamblers and a Non-Psychiatric Control Group Taking Gender Differences into Account
}

\author{
Enrique Echeburúa ${ }^{1}$, Itxaso González-Ortega ${ }^{2}$, Paz de Corral ${ }^{1}$ and Rocío Polo-López ${ }^{1}$ \\ 1 Universidad del País Vasco UPV/EHU (Spain) \\ ${ }^{2}$ Centro de Investigación Biomédica en Red de Salud Mental-CIBERSAM (Spain)
}

\begin{abstract}
The current study aimed to identify personality traits, emotional states and adjustment variables in a sample of pathological gamblers as compared to a non-gambling control group taking gender differences into account. The sample for this study consisted of 206 subjects (103 pathological gamblers and 103 non-psychiatric subjects from the general population matched for age and gender). Pathological gamblers had a lower educational level and a family history of alcohol abuse higher than non-gamblers. In turn, female gamblers were affected by unemployment and a lower socioeconomic status more often than female non-gamblers. Pathological gamblers were more anxious and impulsive and suffered from a poorer self-esteem than non-gamblers. Likewise, pathological gamblers had a greater history of other Axis I psychiatric disorders and were more often affected by anxiety and depression symptoms and showed a more problematic adjustment to everyday life than non-gamblers. Alcohol abuse was not higher in pathological gamblers than in non-gamblers, but, when gender was taken into account, male gamblers were more affected by alcohol abuse than male non-gamblers. Importantly $68.6 \%$ of female gamblers versus $9.8 \%$ of control group women reported being victims of intimate partner violence. These findings can be used to specifically inform prevention and intervention efforts.
\end{abstract}

Received 2 August 2011; Revised 10 October 2011; Accepted 10 January 2012

Keywords: pathological gambling, psychopathology, gender differences, intimate partner violence.

Over the past several decades there has been a significant increase in the availability of legalized gambling in the developed countries. Most people gamble without developing pathological gambling. However, pathological gambling (PG), which is defined in the DSM-IV-TR (American Psychiatric Association, 2000) as "a persistent and recurrent maladaptive gambling behavior that disrupts personal, family or vocational pursuits", has sharply increased in most western countries as a result of the expansion of the gambling industries (Dowling, Smith, \& Thomas, 2007). It is generally estimated that between $2 \%$ and $5 \%$ of the

\footnotetext{
Correspondence concerning this article should be addressed to Enrique Echeburúa. Facultad de Psicología. Avda. de Tolosa, 70. 20018 San Sebastián. (Spain).

E-mail: enrique.echeburua@ehu.es

This work was supported by the Spanish Ministerio de Educación e Innovación (Code PSI2008-03718). The authors express their appreciation to Beatriz Yubero, Lorena Pidal, Beatriz Alonso and Damas Salesianas (Ekintza Dasalud, Rentería); Mercè Soms (Hospital Santa Caterina, Girona); Dominica Díez Marcet (Divisió de Salut MentalAlthaia, Manresa); Nuria Aragay (Servicio de Psiquiatría del Hospital de Tarrasa, Barcelona); Rocío Fonseca and Estíbaliz Rodríguez (Ekintza Aluviz, Baracaldo); Idoia Axpe, Ana Herrezuelo and Raquel Beltrán de Heredia (Asajer, Vitoria); Carlos Caso and Natalia Mendiola (Servicio de Alcoholismo y de Ludopatía de Osakidetza, Vitoria); Koldo Basterra (Hospital Psiquiátrico de Álava, Vitoria); Ana Ruiz (Aralar, Pamplona); José Vicente Marín (Azajer, Zaragoza); and Montse Gómez (Barcelona).
}

adult population in representative community samples are problem or pathological gamblers (Volberg, 2007).

Apart from the role played by cognitive distortions about gambling (Labrador \& Mañoso, 2005; Meyer de Stadelhofen, Aufrère, \& Rossier, 2009), personality studies have described high levels of sensation seeking and impulsivity and low levels of self-esteem among pathological gamblers, even when compared with other clinical groups or healthy controls (Echeburúa \& Fernández-Montalvo, 2008; Fernández-Montalvo \& Echeburúa, 2004). Actually the role played by impulsivity in the development of pathological gambling has been stressed by other studies (Blaszczynski, Steel, \& McConaghy, 1997; Steel \& Blaszczynski, 2002). And some specific personality traits have been found to be gender specific (most of all, harm avoidance in female pathological gamblers) (Granero et al., 2009).

High rates of psychiatric history, psychopathological symptoms, such as negative emotional states (especially depression and anxiety) or alcohol/drug abuse, have been found in pathological gamblers as compared to controls (Desai, Maciejewski, Pantalon, \& Potenza, 2006; Desai \& Potenza, 2008; Ibáñez et al., 2001; Kaare, Mõttus, \& Konstabel, 2009). Psychiatric comorbidity is the rule, not the exception, for persons with PG. While the precise mechanism behind these observations is unclear, there are several possible 
explanations. Gambling may be a way to cope with primary depressive symptoms in pathological gamblers, as it has been found in several studies (Granero et al., 2009; Ledgerwood \& Petry, 2006), but depression may be also secondary to negative consequences of PG. Clinicians who assess and treat these individuals would benefit from understanding the scope and direction of these associations (Echeburúa, FernándezMontalvo, \& Báez, 2001).

Historically, gambling has been a predominantly male pastime; however, as legalised gambling has expanded, female participation has increased and there is evidence that gambling problems have increased among women in recent years. And so it is interesting to consider the relationship between gambling and gender. Men frequently begin gambling early in life, report slow emergence of problems, and seek help well after developing problems; alternativeley, women start gambling later in life, then rapidly develop a problem and seek help more quickly (Blanco, Hasin, Petry, Stinson, \& Grant, 2006; LaPlante, Nelson, Labrie, \& Shaffer, 2006).

In turn, the extant literature on the link between gambling and intimate partner violence (IPV) is limited. IPV histories are common among pathological gamblers (Affi, Bronridge, MacMillan, \& Sareen, 2010; Liao, 2008; Korman et al., 2008). For example, the odds of exposure to IPV were extremely elevated among women presenting themselves to an emergency department (odds ratio $=10.5 ; 95 \% ; C I=1.3-82)$ if the woman's partner was a problem gambler (Muelleman, Denotter, Wadman, Tran, \& Anderson, 2002). However, there are limited data about the female gamblers who report being victims of IPV when compared to women in general population (Echeburúa, González-Ortega, Corral, \& Polo-López, 2011).

The purpose of the current ex post facto study was to identify personality traits, emotional states and adjustment variables in a sample of pathological gamblers as compared to a non-gambling control group taking gender differences into account. Actually current literature on this topic needs to be updated. According to the aim of this study, we hypothesized that there would be significant differences between pathological gamblers and the control group with respect to sociodemographic, personality and psychopathological variables. The pathological gamblers, when compared to the control group, would have higher scores on trait anxiety, sensation seeking, impulsivity and lower scores in selfesteem. Likewise the pathological gamblers would have higher levels of anxiety and depression and would be with a poorer adjustment to daily life than the control group. Gamblers would also have a higher alcohol abuse than the control group (González-Ortega, Echeburúa, Corral, Polo-López, \& Alberich, 2013).

\section{Method}

\section{Participants}

The sample for this study consisted of 206 subjects (103 pathological gamblers and 103 non-psychiatric subjects from general population). All study participants provided voluntary written informed consent.

Pathological gamblers included 103 consecutively referred adult outpatients (51 women and 52 men) meeting current DSM-IV-TR criteria for PG involved in slot machines and/or in bingo. Subjects were recruited over a 5-year period (2005-2009). All of them sought treatment in different Units of Pathological Gambling all over Spain because of their problems and impairment related to PG. Most of the pathological gamblers (75 subjects) were enrolled in the Asociación de Ayuda a Ludópatas Ekintza-Dasalud (Rentería, Guipúzcoa). The Units of Pathological Gambling that participated in the sample recruitment are pointed out in the paragraph of acknowledgements.

All patients were included if they met the inclusion criteria: a) primary diagnosis of current DSM-IV-TR PG; b) age 18 or older. The only exclusion criterion was the presence of a psychotic disorder, mental retardation, dementia or inability to understand and consent to the study. There were not any excluded patients.

The non-psychiatric control group (51 women and 52 men) were similar people, but without a history of PG or any other mental disorder, selected among the normal population and matched up in age and sex with the clinical group. Subjects were found among office workers $(n=60)$ and in a canning factory $(n=43)$ who were asked to collaborate in research and were encouraged to do so by offering them feedback on their personality test results. In short, the mean age for both groups was 43.25 years $(S D=13.6)$.

\section{Measures}

The proposed measures were chosen based on the following criteria: have been used in previous studies on the subject, have good psychometric properties and have been adapted to Spanish.

\section{Personality traits}

Trait Anxiety Inventory (STAI-T) (Spielberger, Gorsuch, \& Lushene, 1970; Spanish version of TEA, 1982). The STAI-T consists of 20 items related to anxietytrait. The range of scores is from 0 to 60 . The internal consistency of the STAI in this study was .85.

Impulsiveness Scale (BIS-10) (Barratt, 1994; Spanish version of Oquendo et al., 2001). The BIS-10 consists of 33 items aimed at assessing the impulsivity (range: 0-132). The internal consistency of the BIS in this study was .78. 
Sensation-Seeking Scale (SSS-V) (Zuckerman, Eysenck, \& Eysenck, 1978). The SSS-V consists of 40 items aimed at determining the level of sensation seeking disposition. The range of scores is from 0 to 40 . The internal consistency of the SSS in this study was .81 .

Self-Esteem Scale (RSE) (Rosenberg, 1965; Spanish version by Fernández-Montalvo \& Echeburúa, 1997). The aim of the RSE is to assess the feeling of satisfaction that a person has about him or herself. There are 10 general items, each one carrying a score between 1 and 4 on a Likert-type scale, giving a questionnaire range from 10 to 40 . The internal consistency of the RSE in this study was .76.

\section{Psychopathological factors}

State Anxiety Inventory (STAI-S) (Spielberger et al., 1970; Spanish version of TEA, 1982). The STAI-S consists of 20 items related to the anxiety-state. The range of scores is from 0 to 60 . The internal consistency of the STAI in this study was .85 .

Beck Depression Inventory (BDI) (Beck, Steer, \& Brown, 1996; Spanish version of Sanz, Vázquez, \& Navarro, 2003). The BDI consists of 21 items and measures the severity of symptoms of depression (range: 0-63). The internal consistency of the BDI in this study was .89.

Alcohol Use Disorders Identification Test (AUDIT) (Saunders, Aasland, Babor, de la Fuente, \& Grant, 1993; Spanish version of Rubio, Bermejo, Caballero, \& Santo Domingo, 1998). The AUDIT was designed by the World Health Organization to screen and identify people who are at risk of developing alcohol problems. This test focuses on identifying the preliminary signs of hazardous drinking and mild dependence. It consists of only 10 questions referred to the quantity and frequency of alcohol consumption, to the drink behavior and to the reactions or problems related to alcohol within the last year (range: 0-36). The internal consistency of the AUDIT in this study was .79.

\section{Adjustment variables}

Misadjustment Scale (IS) (Echeburúa, Corral, \& Fernández-Montalvo, 2000). The IS reflects the extent to which the subject's gambling problems affect to the maladjustment in everyday life: social, work, leisure, couple and family (range: 0-30). The internal consistency of the IS in this study was .83 .

Intimate partner violence (IPV)

Intimate partner violence was assessed using several indicators of violence taken from the items of the Conflict Tactics Scale (CTS2) (Straus, Hamby, BoneyMcCoy, \& Sugarman, 1996; Spanish version of Calvete,
Corral, \& Estévez, 2007) referred to the scales of physical assault, psychological aggression and sexual coercion. The internal consistency of the CTS in this study was .85 .

These measures, validated in Spanish samples, have been extensively used in research and clinical practice, and there is substantial evidence to support their psychometric properties in the field of PG (Dowling et al., 2007; Echeburúa \& Fernández-Montalvo, 2008; Fernández-Montalvo \& Echeburúa, 2004; Granero et al., 2009).

\section{Procedure}

For subjects entering this study, informed consent was obtained after they had been given a detailed written and verbal description of the study. DSMIV-TR diagnostic criteria were screened by means of the Structured Clinical Interview for Pathological Gambling (SCI-PG) (Grant, Steinberg, Kim, Rounsaville, \& Potenza, 2004). The presence/absence of other psychiatric disorders (Axis I) was determined using the Structured Clinical Interview for DSM-IV Axis I Disorders (SCID-I) (First, Spitzer, Gibbon, \& Williams, 1997). These interviews were carried out independently by two experienced clinical psychologists. The data on interrater reliability obtained with these interviews in this study were satisfactory (kappa $=.91$ and kappa $=.88$ respectively).

Participants were assessed individually using a semistructured face-to-face interview that focused on different aspects of demographic characteristics. The subjects then individually filled in all the questionnaires included in the study during two assessment sessions.

The study was approved by the University Ethics Committee and by the Ethics Committees of the different Hospitals involved in this research.

\section{Data analysis}

Differences between the two groups were tested for significance with Pearson's chi-square test for dichotomous variables and $t$-tests for quantitative psychological features. Non-parametric alternative to the $t$-test (Mann-Whitney $U$ ) was used when there was reason to believe that data were not normally distributed. Effect sizes based on Cohen's d (1988) and Chuprov's $T^{2}$ estimated the clinical differences. The results were interpreted as small if $d / T^{2}$ values ranged between .2 and .49 , medium if $d / T^{2}$ values ranged between .5 and .79 , and large if $d / T^{2}$ values were higher than .8.A multivariate logistic regression analysis was performed to analyze the relationship between sociodemographic, personality and psychopathological variables with pathological gambling. All independent 
variables that were found to be significant in the analysis for comparison of means between two groups (gamblers / control group) were included in the regression analysis. Gender variable was introduced in the model in order to determine its influence in the relationship between the dependent variable (being a pathological gambler or not) and the independent variables. Logistic regression analyses were also performed separately for men and women.

The paragraphs below present first the results of both groups comparisons on sociodemographic characteristics. These are followed by the differences in personality and psychopathological variables. A gender comparison between pathological gamblers and the non-psychiatric control group (male gamblers versus male non-gamblers and female gamblers versus female non-gamblers) is taken into account in all measures. Results of the specific differences for men/women with PG in the studied variables have been published in a separate paper (Echeburúa et al., 2011). Finally, the rates of intimate partner violence are compared between women gamblers and the control group women.

\section{Results}

\section{Sociodemographic characteristics}

The main demographics regarding differences between the two groups are displayed in Table 1. Overall, there were no differences between the two groups, except in the educational level and in the family history of alcohol abuse: pathological gamblers had a lower educational level and a family history of alcohol abuse higher than the control group subjects.However, when gender was taken into account, there were some additional significant differences in employment status and in socioeconomic level. Women pathological gamblers had a higher levels of unemployment, $\chi^{2}(3)=9.32, p<.05$, and a lower socioeconomic status, $\chi^{2}(4)=13.098$, than women in the control group.

\section{Personality, psychopathology and adjustment variables}

As far as personality and psychopathological factors are concerned, the main differences between the two groups are examined in Table 2. Overall, pathological gamblers were more anxious and impulsive and suffered from a poorer self-esteem than subjects from the non-psychiatric control group. There were no genderrelated differences in these variables.

Regarding psychiatric history, pathological gamblers had a greater history of several other Axis I psychiatric disorders $(50.5 \%)$ than subjects from the non-psychiatric control group $(13.6 \%), \chi^{2}(1)=32.193, p<.001$. Anxiety and mood disorders and substance abuse were the most frequent disorders. Males and females did not differ significantly regarding this variable.

In our study pathological gamblers were more often affected by anxiety and depression symptoms and showed a more problematic adaptation to everyday life than subjects from the control group. There were no gender-related differences in these variables.

In turn, alcohol abuse in pathological gamblers was not consistently higher than in normal subjects. However, when gender was taken into account, male gamblers $(M=6.09 ; S D=4.52)$ were more affected by alcohol abuse than men in the control group $(M=3.78$; $S D=3.22), t=-2.833 ; p<.01$. However, female gamblers $(M=3.27 ; S D=6.22)$ and female in control group $(M=2.16 ; S D=2.10)$ did not differ significantly, $t=-.433$, $n s$, regarding this variable.

Relationship between sociodemographic, personality and psychopathological variables with pathological gambling taking gender into account

A multivariate logistic regression analysis was performed to analyze the relationship between pathological gambling and the sociodemographic, personality and psychopathological variables found to be statistically significant in the previous analysis for comparison of means. Gender (being male), the educational level (uneducated or primary school), the trait of impulsivity, the misadjustment to everyday life and the depressive symptoms were associated with the group of pathological gamblers (Table 3).

Finally, logistic regression analyses were performed separately for men and women taking into account the significant effect of the variable "gender" in the regression analysis for the overall sample. In the case of men, the trait of impulsivity, $\beta=-.201, p=.003$, and the depressive symptoms, $\beta=-.244, p=.002$, were associated with pathological gambling, while for women a low educational level, $\beta=-4,588, p<.01$, the depressive symptoms, $\beta=-.123, p<.05$, and the misadjustment to everyday life, $\beta=-.210, p=.005$, were related to the group of women gamblers.

\section{Intimate partner violence (IPV)}

Importantly, $68.6 \%$ of the female gamblers versus $9.8 \%$ of control group women reported being victims of intimate partner violence now or in the recent past (Table 4).

\section{Discussion}

This study aimed to identify personality traits, emotional states and adjustment variables in a sample of pathological gamblers taking gender differences into 
Table 1. Socio-demographic characteristics

\begin{tabular}{|c|c|c|c|c|c|c|}
\hline & \multicolumn{2}{|c|}{$\begin{array}{l}\text { Pathological gamblers } \\
(N=103)\end{array}$} & \multicolumn{2}{|c|}{$\begin{array}{l}\text { Non-psychiatric control } \\
\text { group }(N=103)\end{array}$} & \multirow[b]{2}{*}{$\chi^{2}(d f)$} & \multirow[b]{2}{*}{$T^{2}$} \\
\hline & $N$ & $\%$ & $N$ & $\%$ & & \\
\hline \multicolumn{7}{|l|}{ Family status } \\
\hline Married & 44 & 42.7 & 52 & 51.5 & $3.290(3)$ & \\
\hline Single & 35 & 34.0 & 35 & 34.7 & & \\
\hline Divorced & 15 & 14.6 & 9 & 8.9 & & \\
\hline Widower & 9 & 8.7 & 5 & 5.0 & & \\
\hline \multicolumn{7}{|l|}{ Educational level } \\
\hline Uneducated & 5 & 4.9 & 2 & 1.9 & $11.104(3)^{* * *}$ & .03 \\
\hline Primary school & 57 & 55.9 & 37 & 35.9 & & \\
\hline High school & 30 & 29.4 & 47 & 45.6 & & \\
\hline College & 10 & 9.8 & 17 & 16.5 & & \\
\hline \multicolumn{7}{|l|}{ Employment status } \\
\hline Active & 52 & 52.0 & 65 & 63.1 & $7.349(3)$ & \\
\hline Unemployment & 32 & 32.0 & 29 & 28.2 & & \\
\hline Retirement & 4 & 4.0 & 6 & 5.8 & & \\
\hline Prolonged low & 12 & 12.0 & 3 & 2.9 & & \\
\hline \multicolumn{7}{|l|}{ Socioeconomic level } \\
\hline Low & 13 & 12.7 & 3 & 2.9 & $8.921(4)$ & .08 \\
\hline Medium-low & 16 & 15.7 & 16 & 15.5 & & \\
\hline Medium & 62 & 60.8 & 70 & 68.0 & & \\
\hline Medium-high & 8 & 7.8 & 13 & 12.6 & & \\
\hline High & 3 & 2.9 & 1 & 1.0 & & \\
\hline Family history of alcohol abuse & & & & & $18.362(1)^{* * *}$ & \\
\hline No & 66 & 64.1 & 92 & 89.3 & & \\
\hline Yes & 37 & 35.9 & 11 & 10.7 & & \\
\hline
\end{tabular}

Note: $p<.05^{*} p<.01^{* *} p<.001^{* * *}$

Table 2. Personality traits and psychopathological factors

\begin{tabular}{|c|c|c|c|c|c|c|}
\hline \multirow[b]{2}{*}{ Personality Traits } & \multicolumn{2}{|c|}{$\begin{array}{l}\text { Pathological gamblers } \\
(N=103)\end{array}$} & \multicolumn{2}{|c|}{$\begin{array}{l}\text { Non-psychiatric control } \\
\text { group }(N=103)\end{array}$} & \multirow[b]{2}{*}{$t / z^{1}$} & \multirow[b]{2}{*}{$d$} \\
\hline & $M$ & $S D$ & $M$ & $S D$ & & \\
\hline Anxiety (STAI-T) & 30.05 & 11.41 & 18.29 & 8.93 & $8.140^{* * *}$ & 1.1 \\
\hline Impulsivity (BIS-10) & 63.70 & 16.57 & 45.66 & 11.78 & $8.207^{* * *}$ & 1.2 \\
\hline Sensation seeking (SSS) & 16.73 & 5.56 & 16.57 & 6.70 & 0.175 & \\
\hline Self-esteem (RSE) & 26.71 & 5.10 & 33.04 & 5.66 & $-8.384^{* * *}$ & -1.2 \\
\hline \multicolumn{7}{|l|}{ Psychopathological Factors } \\
\hline Anxiety (STAI-S) & 27.94 & 10.58 & 18.48 & 9.25 & $6.584^{* * *}$ & .9 \\
\hline Depression (BDI) & 19.52 & 12.31 & 6.82 & 5.59 & $-8.304^{* * *}$ & 1.3 \\
\hline Misadjustment Scale (IS) & 17.10 & 7.27 & 10.27 & 4.86 & $-6.934^{* * *}$ & 1.1 \\
\hline Alcohol abuse (AUDIT) & 4.69 & 5.58 & 2.98 & 2.83 & -1.614 & \\
\hline
\end{tabular}

Note: $p<.05^{*} p<.01^{* *} p<.001^{* * *} \mathrm{Z}^{1}$ : U Mann-Whitney statistical (non-parametric tests)

account as compared to a non-gambling control group. That is, the study was also designed to explore gender as a critical factor for pathological gambling. The findings indicate that there were relevant differences which may be considered to plan an effective intervention regarding prevention and treatment.

Our first finding related to demographics was that, according to other studies (Ibáñez et al., 2001; Kaare et al., 
Table 3. Multivariate logistic regression between pathological gambling and sociodemographic, personality and psychopathological variables

\begin{tabular}{|c|c|c|c|c|c|}
\hline & \multirow[b]{2}{*}{$\beta$} & \multirow[b]{2}{*}{$B$} & \multicolumn{2}{|l|}{$95 \% \mathrm{CI}$} & \multirow[b]{2}{*}{$p$} \\
\hline & & & Inferior & Superior & \\
\hline \multicolumn{6}{|c|}{ Educational level (ref.: College) } \\
\hline Uneducated & -3.048 & .047 & .004 & .626 & .021 \\
\hline Primary school & -3.803 & .022 & .004 & .127 & .001 \\
\hline High school & .299 & -1.206 & .070 & 1.282 & .104 \\
\hline Gender & -1.518 & .219 & .060 & .804 & .022 \\
\hline Self-esteem (RSE) & 1.110 & .105 & .974 & 1.241 & .125 \\
\hline Impulsivity(BIS) & -.049 & .952 & .913 & .993 & .021 \\
\hline Anxiety (STAI-T) & 1.016 & .016 & .939 & 1.098 & .764 \\
\hline Anxiety (STAI-S) & .990 & -.010 & .924 & 1.060 & .694 \\
\hline Depression (BDI) & -.149 & .862 & .792 & .937 & .001 \\
\hline Misadjustment (IS) & -122 & .885 & .805 & .972 & .011 \\
\hline
\end{tabular}

Table 4. Women of both groups suffering from intimate partner violence

\begin{tabular}{|c|c|c|c|c|c|c|}
\hline & \multicolumn{2}{|c|}{ Women Gamblers } & \multicolumn{2}{|c|}{ Control Group Women } & \multirow[b]{2}{*}{$\chi^{2}(d f)$} & \multirow[b]{2}{*}{$T^{2}$} \\
\hline & $n$ & $\%$ & $n$ & $\%$ & & \\
\hline With intimate partner violence & 35 & 68.6 & 5 & 9.8 & $37.016(1)^{* * *}$ & .35 \\
\hline Without intimate partner violence & 16 & 31.4 & 46 & 90.2 & & \\
\hline TOTAL & 51 & 100 & 51 & 100 & & \\
\hline
\end{tabular}

Note: $p<.001^{* * *}$

2009), pathological gamblers had a lower educational level and a family history of alcohol abuse higher than non-gamblers. This fact may partially account for a higher gambling involvement. In terms of gender differences, female gamblers were affected by unemployment and a lower socioeconomic status more often than female non-gamblers. These differences, probably related to traditional gender roles, have also been partially found in other studies (Desai et al., 2006; Granero et al., 2009).

There were significant differences in personality traits between the two groups. Overall, pathological gamblers were more anxious and impulsive and suffered from a poorer self-esteem than non-gamblers (Echeburúa et al., 2001). Further research is needed to know if people with these personality traits are more vulnerable to gambling. These results are partially consistent with previous studies (Blaszczynski et al., 1997; Echeburúa \& Fernández-Montalvo, 2008; FernándezMontalvo \& Echeburúa, 2004; Kaare et al., 2009). In other studies the studied personality traits were not exactly the same (Granero et al., 2009). One interesting finding of our study is the lack of significant differences between the two groups in terms of mean sensationseeking scores. Although high levels of sensation seeking have been described among pathological gamblers (e.g. Blaszczynski et al., 1997; Echeburúa \& FernándezMontalvo, 2008; Fernández-Montalvo \& Echeburúa, 2004), it is possible that other personality traits, such as impulsivity, may play a major role in the development and maintenance of PG. This finding is important to take it into consideration both for prevention and even for treatment strategies. Psychological treatment of PG should include some components focused on the reduction of impulsivity.

Regarding psychopathology, gamblers were found to have a greater history of other Axis I psychiatric disorders (most of all, anxiety and mood disorders and substance abuse) than non-gamblers. Currently gamblers reported more negative emotional estates (anxiety and depression symptoms) and a more problematic adaptation to everyday life than non-gamblers. One possibility is that gambling can be used for regulating negative emotional states associated with life 
events. Psychiatric comorbidity for persons with PG has also been found in other studies (Ibáñez et al., 2001; Kaare et al., 2009; Petry, Stinson, \& Grant, 2005). There were no gender-differences in these variables. Anyway these findings suggest that treatment for PG should involve assessment and possible concomitant treatment for comorbid conditions.

In terms of alcohol abuse, surprinsingly there were no differences in this variable between the two groups. However, when gender was taken into account, male gamblers were more affected by alcohol abuse than male non-gamblers. Alcohol can be used as a strategy to cope with emotional trouble in men (Blanco et al., 2006). These results are partially consistent with previous studies (Granero et al., 2009; Ibáñez et al., 2001; Petry et al., 2005). Treatment for PG should always pay attention to other comorbid addictions.

According to the multivariate logistic regression in our study, the gender (being male), a low educational level, the trait of impulsivity, the misadjustment to everyday life and the depressive symptoms were related to PG. In terms of gender differences, the trait of impulsivity and the depressive symptoms were associated with men pathological gamblers, while a low educational level, the depressive symptoms and the misadjustment to everyday life were associated with women gamblers. These findings reflect that certain sociodemographic, personality and clinical characteristics may predispose to the development of PG. In addition, the role played by the gender factor in PG suggests that certain features are specific to men and women and that there is a differential psychopathological profile of men and women gamblers (Echeburúa et al., 2011), which should be taken into consideration both for prevention and for treatment strategies.

Importantly, nearly seven out of every ten female gamblers reported being victims of intimate partner violence (IPV) (including dating and marital violence). This rate is seven times higher than that registered in Spain for women over 18 years (Echeburúa, Sarasua, Zubizarreta, \& Corral, 2009; Echeburúa, Sarasua, Zubizarreta, Amor, \& Corral, 2010; Instituto de la Mujer, 2006). These results have been also found in other studies elsewhere with a nationally representative sample (Affi et al., 2010). There are different kinds of explanation that can take account of this result. That is, gambling may be a way to escape from a violent relationship, but IPV may be also related to domestic conflict caused or exacerbated by financial or other stressors directly associated with gambling activities. Little attention has been given to prevention of gambling problems as a factor in reducing IPV. All these findings highlight the importance of routinely screening gambling patients for anger and IPV and disrupted behavior in children, and the need to develop public policy, prevention and treatment programs to address these problems (Echeburúa, Corral, \& Amor, 2002; Liao, 2008; Picó-Alfonso, Echeburúa, \& Martínez, 2008).

This study has both theoretical and applied implications. The accurate understanding of personality and clinical characteristics in pathological gamblers could help to guide further research regarding prevention and treatment decisions according to the patient's emotional states/patterns (Echeburúa \& FernándezMontalvo, 2005; Echeburúa et al., 2011).

The limitations of the current research should be considered when interpretating the study findings. First, the relatively small sample size precludes a definitive conclusion regarding differences between the two groups. Methodologically it is important to keep in mind that treatment seekers might not be representative of gamblers in general population. Since a treatmentseeking sample was used, it is unclear how generalizable our results are to non-treatment seeking individuals with PG. Additional research on this topic is needed, including larger prevalence studies both in clinical settings and using nationally representative data. Second, a more complete assessment of mental symptoms and comorbid disorders, including Axis II disorders, needs to be dealth with in future research. Third, the data used in the current research were cross-sectional, which means that inferences regarding causation cannot be made. Longitudinal designs are required to address the role of comorbid disorders on course and outcome, illness progression, and treatment. Finally, the self-reported nature of the data can lead to recall bias. Anyway, endogenous and exogenous conditions need to be explored in future research as being gender-related operating factors.

\section{References}

Affi T. O., Bronridge D. A., MacMillan H., \& Sareen J. (2010). The relation of gambling to intimate partner violence and child maltreatment in a nationally representative sample. Journal of Psychiatric Research, 44, 331-337. http:/ / dx.doi. org/10.1016/j.jpsychires.2009.07.010

American Psychiatric Association (2000). Diagnostic and statistical manual of mental disorders (4 ${ }^{\text {th }} E d$. Rev.), Washington, DC: APA.

Barratt E. S. (1994). Impulsiveness and aggression. In J. Monahan \& H. J. Steadman (Eds.), Violence and mental disorder: Development in risk assessment (pp. 61-79). Chicago, IL: University of Chicago Press.

Beck A. T., Steer R. A., \& Brown G. K. (1996). BDI-II. Beck Depression Inventory-2 ${ }^{\text {nd }}$ Ed. manual. San Antonio, TX: The Psychological Corporation.

Blanco C., Hasin D. S., Petry N., Stinson F. S., \& Grant B. F. (2006). Sex differences in subclinical and DSM-IV pathological gambling: Results from the National Epidemiologic Survey on alcohol and related conditions. 
Psychological Medicine, 36, 943-953. http:/ / dx.doi. org/10.1017/S0033291706007410

Blaszczynski A., Steel Z., \& McConaghy N. (1997). Impulsivity in pathological gambling: The antisocial impulsivist. Addiction, 92, 75-87. http:/ /dx.doi. org/10.1111/j.1360-0443.1997.tb03639.x

Calvete E., Corral S., \& Estévez A. (2007). Factor structure and validity of the Revised Conflict Tactics Scale for Spanish women. Violence Against Women, 13, 1072-1087. http:/ / dx.doi.org/10.1177/1077801207305933

Cohen J. (1988). Statistical power analysis for the behavioral sciences (2nd Ed.), Hillsdale, NJ: Erlbaum.

Desai R. A., Maciejewski P. K., Pantalon M. V., \& Potenza M. N. (2006). Gender differences among recreational gamblers: Association with the frequency of alcohol use. Psychology of Addictive Behaviors, 20, 145-153. http:/ / dx.doi.org/10.1037/0893-164X.20.2.145

Desai R. A., \& Potenza M. N. (2008). Gender differences in the associations between past-year gambling problems and psychiatric disorders. Social Psychiatry and Psychiatric Epidemiology, 43, 173-183. http:/ /dx.doi.org/10.1007/ s00127-007-0283-z

Dowling N., Smith D., \& Thomas T. (2007). A comparison of individual and group cognitive-behavioural treatment for female pathological gambling. Behaviour Research and Therapy, 45, 2192-2202. http:/ /dx.doi.org/10.1016/j. brat.2006.11.003

Echeburúa E., Corral P., \& Amor P.J. (2002). Evaluación del daño psicológico en las víctimas de delitos violentos. [Evaluation of psychological harm in the victims of violent crime]. Psicothema, 14 (Supl.), 139-146.

Echeburúa E., Corral P., \& Fernández-Montalvo J. (2000). Escala de Inadaptación: Propiedades psicométricas en contextos clínicos [Misadjustment Scale: Psychometric properties in a clinical context]. Análisis y Modificación de Conducta, 26, 325-340.

Echeburúa E., \& Fernández-Montalvo J. (2005). Psychological treatment of slot-machine pathological gambling: New perspectives. Journal of Gambling Studies, 21, 21-26. http:/ / dx.doi.org/10.1007/s10899-004-1918-6

Echeburúa E., \& Fernández-Montalvo J. (2008). Are there more personality disorders in treatment-seekers pathological gamblers than in other kind of patients? A comparative study between the IPDE and the MCMI. International Journal of Clinical and Health Psychology, 8, 53-64.

Echeburúa E., Fernández-Montalvo J., \& Báez C. (2001). Predictors of therapeutic failure in slot-machine pathological gamblers following behavioural treatment. Behavioural and Cognitive Psychotherapy, 29, 379-383. http:/ / dx.doi.org/10.1017/S1352465801003113

Echeburúa E., González-Ortega I., Corral P., \& Polo-López R. (2011). Clinical gender differences among adult pathological gamblers seeking treatment: An exploratory study. Journal of Gambling Studies, 27, 215-227. http:/ / dx. doi.org/10.1007/s10899-010-9205-1

Echeburúa E., Sarasua B., Zubizarreta I., \& Corral P. (2009). Evaluación de la eficacia de un tratamiento cognitivoconductual para hombres violentos contra la pareja en un marco comunitario: Una experiencia de 10 años (1997-2007)
[Effectiveness of a cognitive-behavioral programme in the treatment of male batterers in a community setting: A review of ten years (1997-2007)]. International Journal of Clinical and Health Psychology, 9, 199-217.

Echeburúa E., Sarasua B., Zubizarreta I., Amor P. J., \& Corral P. (2010). Variables predictoras del rechazo, abandono y fracaso terapéutico en hombres violentos contra su pareja tratados psicológicamente en un marco comunitario [Predictors of refusal, dropout and therapeutic failure among men attending a community batterer treatment program]. International Journal of Clinical and Health Psychology, 10, 403-420.

Fernández-Montalvo J., \& Echeburúa E. (1997). Manual práctico del juego patológico. Ayuda para el paciente y guía para el terapeuta [Practical handbook for the treatment of pathological gambling. A guide for the patient and the therapist]. Madrid, Spain: Pirámide.

Fernández-Montalvo J., \& Echeburúa E. (2004). Pathological gambling and personality disorders: An exploratory study with the IPDE. Journal of Personality Disorders, 18, 500-505. http://dx.doi.org/10.1521\%2Fpedi.18.5.500.51326

First M. B., Spitzer R. L., Gibbon M., \& Williams J. B. W. (1997). User's guide for the Structured Clinical Diagnostic Interview for DSM-IV Axis I Disorders (SCID-I). Washington, DC: American Psychiatric Press.

González-Ortega I., Echeburúa E., Corral P., Polo-López R., \& Alberich S. (2013). Predictors of pathological gambling severity taking gender differences into account. European Addiction Research, 19, 146-154. http:/ /dx.doi.org/ 10.1159/000342311

Granero R., Penelo E., Martínez-Giménez R., ÁlvarezMoya E., Gómez-Peña M., Aymamí M. N., ... JiménezMurcia S. (2009). Sex differences among treatmentseeking adult pathologic gamblers. Comprehensive Psychiatry, 50, 173-180. http://dx.doi.org/10.1016/ j.comppsych.2008.07.005

Grant J. E., Steinberg M. A., Kim S. W., Rounsaville B. J., \& Potenza M. N. (2004). Preliminary validity and reliability testing of a structured clinical interview for pathological gambling. Psychiatry Research, 128, 79-88. http:/ /dx.doi. org/10.1016/j.psychres.2004.05.006

Ibáñez A., Blanco C., Donahue E., Lesieur H. R., Pérez de Castro I., \& Fernández-Piqueras J. (2001). Psychiatric comorbidity in pathological gamblers seeking treatment. American Journal of Psychiatry, 158, 1733-1735. http:/ /dx. doi.org/10.1176/appi.ajp.158.10.1733

Instituto de la Mujer (2006). La violencia contra las mujeres. Resultados de la macroencuesta [Violence against women: Results from a big survey]. Madrid, Spain: Ministerio de Trabajo y Asuntos Sociales.

Kaare P. R., Mõttus R., \& Konstabel K. (2009). Patological gambling in Estonia: Relationships with personality, self-esteem, emotional states and cognitive ability. Journal of Gambling Studies, 25, 377-390. http: / /dx.doi. org /10.1007/s10899-009-9119-y

Korman L. M., Collins J., Dutton, Dhayananthan B., Littman-Sharp N., \& Skinner W. (2008). Problem gambling and intimate partner violence. Journal of Gambling Studies, 24, 13-23. http:/ /dx.doi.org/10.1007/ s10899-007-9077-1 
Labrador F. J., \& Mañoso V. (2005). Cambio en las distorsiones cognitivas de jugadores patológicos tras el tratamiento: Comparación con un grupo control [Restructuring of cognitive distortions in pathological gamblers after treatment: Comparison with a control group]. International Journal of Clinical and Health Psychology, 5, 7-22.

LaPlante D. A., Nelson S. E., LaBrie R. A., \& Shaffer H. J. (2006). Men and women playing games: Gender and the gambling preferences of Iowa Gambling Treatment Program participants. Journal of Gambling Studies, 22, 65-80. http:/ / dx.doi.org/10.1007/s10899005-9003-3

Ledgerwood D. M., \& Petry N. M. (2006). Psychological experience of gambling and subtypes of pathological gambling. Psychiatry Research, 144, 17-27. http:/ /dx.doi. org/10.1016/j.psychres.2005.08.017

Liao M. S. (2008). Intimate partner violence within the Chinese community in San Francisco: Problem gambling as a risk factor. Journal of Family Violence, 23, 671-678. http:/ /dx.doi.org/10.1007/s10896-008-9190-7

Muelleman R. L., Denotter T., Wadman M. C., Tran T. P., \& Anderson J. (2002). Problem gambling in the partner of the emergency department patient as a risk factor for intimate partner violence. Journal of Emergency Medicine, 23, 307-312. http:/ / dx.doi.org/10.1016/S07364679(02)00543-7

Oquendo M. A., Baca-García E., Graver R., Morales M., Montalbán V., \& Mann J. J. (2001). Spanish adaptation of the Barrat Impulsiveness Scale (BIS). European Journal of Psychiatry, 15, 147-155.

Petry N. M., Stinson F. S., \& Grant B. F. (2005). Comorbidity of DSM-IV pathological gambling and other psychiatric disorders: Results from the National Epidemiologic Survey on Alcohol and Related Conditions. Journal of Clinical Psychiatry, 66, 564-574. http:/ /dx.doi.org/ 10.4088\%2FJCP.v66n0504

Picó-Alfonso M. A., Echeburúa E., \& Martínez M. (2008). Personality disorder symptoms in women as a result of chronic intimate male partner violence. Journal of Family Violence, 23, 577-588. http:/ / dx.doi.org/10.1007/ s10896-008-9180-9
Rosenberg A. (1965). Society and adolescent self-image. New Jersey, NJ: Princeton.

Rubio G., Bermejo J., Caballero M. C., \& Santo Domingo J. (1998). Validación de la Prueba para la Identificación de Trastornos por Uso de Alcohol (AUDIT) en atención primaria [Spanish validation of the Alcohol Use Disorders Identification Test in primary health care]. Revista Clinica Española, 198, 11-14.

Sanz J., Vázquez C., \& Navarro M. (2003). Adaptación Española del Inventario para la Depresión de Beck-II (BDI-II): Propiedades psicométricas en estudiantes universitarios [Spanish validation of Beck Depression Inventory-II (BDI-II): Psychometric properties in university students]. Análisis y Modificación de Conducta, 29, 239-288.

Saunders J. B., Aasland O. G., Babor T. F., de la Fuente J. R., \& Grant M. (1993). Development of the Alcohol Use Disorders Identification Test (AUDIT): WHO collaborative project on early detection of persons with harmful alcohol consumption-II. Addiction, 88, 791-804. http://dx.doi. org/10.1111/j.1360-0443.1993.tb02093.x

Spielberger C. D., Gorsuch R. L., \& Lushene R. E. (1970). Manual for the State-Trait Inventory. Palo Alto, CA: Consulting Psychological Press.

Steel Z., \& Blaszczynski A. (2002). Impulsivity, personality disorders and pathological gambling severity. In J. J. Marotta, J. A. Cornelius, \& W. R. Eadington (Eds.), The downside: Problem and pathological gambling (pp. 107-123). Reno, NV: University of Nevada.

Straus M. A., Hamby S. L. Boney-McCoy S., \& Sugarman D. B. (1996). The revised Conflict Tactics Scales (CTS2): Development and preliminary psychometric data. Journal of Family Issues, 17, 283-316. http: / / dx.doi.org/ $10.1177 / 019251396017003001$

Volberg R. A. (2007). Populations surveys. In G. Smith, D. C. Hodgins, \& R. J. Williams (Eds.), Research and Measurement Issues in Gambling Studies (pp. 33-54). Amsterdam, The Netherlands: Elsevier.

Zuckerman M., Eysenck S. B. G., \& Eysenck H. J. (1978). Sensation-seeking in England and America: Cross-cultural, age and sex comparisons. Journal of Consulting and Clinical Psychology, 46, 139-149. http:/ / dx.doi.org/10.1037/ / 0022006X.46.1.139 